\title{
The Impact of Visual Merchandising on Impulse Buying Behavior of Consumer: A Case from Central Mall of Ahmedabad India
}

\author{
Neha P. Mehta ${ }^{*}$, Pawan K. Chugan \\ Institute of Management, Nirma University, Ahmedabad, India \\ *Corresponding Author: npmehta_9@yahoo.co.in
}

Copyright @ 2013 Horizon Research Publishing All rights reserved.

\begin{abstract}
Apparel industry in India is booming and there is fierce competition among various players in apparel segment in terms of lifestyle format. The study is aimed to find out impact of various dimensions of visual merchandising on impulse buying behavior of the customers visiting "Central Malls". Four dimensions of visual merchandising viz. window display, in-store form/mannequ in display, floor merchandising and promotional signage are studied and its impact on impulse buying behavior is found out. The results reveal that certain dimensions of visual merchandising do affect impulse purchase. Hence, visual merchandising is important for strategic marketing decisions to increase the sales of the stores.
\end{abstract}

Keywords Visual Merchandising, Window Display, In-Store form/Mannequin Display, Floor Display, Promotional Signage, Impulse Buying

\section{Introduction}

Retail has caught lot of attention in the past one decade. India as the 'second most attractive retail destination' globally among thirty emergent markets (1). In terms of purchasing power parity (PPP), India is ranked $4^{\text {th }}$ largest economy after USA, China and Japan. Indian retail market is growing with the compounded annual growth rate of $46.64 \%$. One of the major contributors is the modernized retail format that is, "The Shopping Mall- the one stop destination". In India, retail industry contributes $10 \%$ of the GDP and $8 \%$ of the employment. The Indian retail market is estimated at US\$ 350 billion. But organized retail is estimated at only US\$ 8 billion. India's overall retail sector is expected to rise at US\$ 833 billion by 2013 at a compound annual growth rate (CAGR) of 10 per cent. The Indian consumer market is likely to grow four times by 2025 (2). India stands $4^{\text {th }}$ in Global Retail Development Index 2011 (1).

The retail sector is witnessing an influx of large domestic conglomerates such as Reliance Group, Future Group and AV Birla Group. In November 2011, Government of India announced reforms in retail sector for both multi-brand stores and single-brand stores. These market reforms paved the way for retail innovations and competition with multi-brand retailers such as Wal-Mart, Carrefour and Tesco, as well as single brand majors such as IKEA, Nike and Apple. In January 2012, Government approved reforms for single-brand stores welcoming anyone in the world to innovate in Indian retail market with $100 \%$ ownership. This development in retail creates fierce competition in the industry. The competition in terms of innovations in organized consumer retail industry has always been avoided by India before 2011. India's organized retail had a $31 \%$ share in clothing and apparel in 2011 (1). Foreign retail chains entering India will aggravate the competition to different level. Hence, the retailers have to ensure that their stores appeal to the customers more effectively. In such case, the retailers need to differentiate themselves from others. The similarity of merchandise in the fashion or apparel forces the industry to utilize visual merchandising to improve the desirability of the product, differentiate their product and enhance the impulse buying behavior. Since the country is getting more competitive in terms of retail industry, visual merchandising is the only effective way of differentiating in apparel industry. The last thing a customer wants is similarity in merchandise. The innovation in store chain is very weak. Indian consumers are becoming more aware about the latest fashion and design and also in the innovation of the apparel store space. They also want state of art products that have good quality and are of global standards and experience that also meets global standards. Visual merchandising is the only technique to create euphoria in apparel industry by store presentation. There are various institutes in the country providing courses on visual merchandising. Retailers by incorporating innovative usage of store space can match the consumers' expectations and give strong competition. Hence, it becomes important to study visual merchandising in apparel industry and help the 
marketers to understand the way they can differentiate themselves from competitors.

\section{Literature Review}

\subsection{Visual Merchandising}

Visual merchandising is effective presentation of products that impacts customers purchase (3). It is providing right product to right customer at right time. It is defined as "the presentation of a store/brand and its merchandise to the customer through the teamwork of the store's advertising, display, special events, fashion coordination, and merchandising departments in order to sell the goods and services offered by store" (4). This means everything that customer sees, exterior or interior, creates a positive impact on customer. Retailers are gradually realizing that only selling the product is not important, but customers' satisfaction and convenience is also important for shopping. Stimulus in retailing includes space related, product related and people related aspects (5). These stimuli are mostly collected through eyes. Hence, it is inexpensive way of marketing (6).

Visual merchandising includes both store exterior and interior. The store exterior includes window display, façade and retail premises. Window display is a medium which creates first impression in customer's mind to enter the store. Physical attractiveness of the store impresses customers highly for store selection (7). In the same way exterior of the store instigates customers to enter the store (8). There are three types of interior display: Merchandising display, Point-of-sales display and Architectural display (9). In-store cues have always been prominal for practitioners and researchers $(10,11)$. Good store interior interests customers and hence, reduces psychological defense and help purchase $(12,3,13,9,14$, and 8$)$. The store interior includes orienting factors (14); signage (13); Layout $(15,16)$, fixturing (15), merchandise (14), presentation techniques (17), props (18) and spatial factors and ambient conditions (14), which Kotler termed "atmospherics" which is a very important strategy. Consumer expectation regarding in-store design have increased (17) and there is also a heightened desire for shopping excitement, which can in part be delivered through innovative design of the physical environment $(19,15)$. Visual merchandising is, therefore, concerned with both how the product/brand is visually communicated to the customer and also whether this message is aptly decoded. Visual merchandising includes various aspects of consumer such as sensory pleasure, affective pleasure and cognitive pleasure (20). Consumers under stress will make planned or nondiscretionary purchase and won't spend as much time or money on unplanned/impulse purchases (21). Customers account both monetary and non-monetary costs of the merchandise (22). Recreational i.e. non-monetary are vital for shopping (23). The longer a shopper remains in store more he or she will buy. And the amount of time the shopper will spend in the store depends on how comfortable or enjoyable the experience is. So the visual stimulus and ambience must be soothing and effective so customer remains in store for longer time. Along with the merchandise, it triggered affective reaction among shoppers (24) which creates store patronage intentions (25). It is evident from the above research studies, that in-store environment is critical component of store choice and sales behavior.

\subsection{Consumer Behavior}

Consumer behavior is long been a study of interest for the researchers. The early work done in this subject came from economic perspective which focused only on act of purchase (38). Consumers are viewed as rational decision makers who are only concerned with self interest (39). There are many contemporary researches done on consumer behavior that considers varied range of factors that influences consumer and proves a broad range of consumption activity beyond purchasing. These activities include need recognition, information search, evaluation of alternatives, building purchase intention, act of purchasing, consumption and finally disposal. This has evolved from various important stages in the past by application of new research methodologies and several approaches that had been adopted. The evolution of this subject has been continuous; it is after 1950's that the field of consumer behavior has responded to the conception and growth of modern marketing to encompass the more holistic range of activities that impact upon the consumer decision (40). The definition of consumer behavior "is the study of the processes involved when individuals or groups select, purchase, use or dispose of products, services, ideas or experiences to satisfy needs and desires" (41). The similar definition of consumer behavior "The behavior that consumer display in searching for, purchasing, using, evaluating and disposing of the products and services that they expect will satisfy their needs" (39). Consumers do not always buy what they want. There are certain unconscious needs. Hence, there is always customers will buy something that they do not necessarily need (42). This means that understanding consumer behavior and knowing them have and never will be simple. Their actions vary from their words. Marketers can apply various stimuli and observe the conduct of consumers. There are numerous model developed on the buying behavior of the consumers. A consumer is influenced by external factors like marketing mix and sociocultural environment, internal factors like psychological field (39). The consumer has to then make a decision which will directly be influenced by their personal characteristics. But, for marketers the end result should be that a consumer makes purchase.

\subsection{Impulse Buying Behavior}

Impulse buying behavior is the purchase that is made without much thinking. It is done without involving much 
evaluation of different things like need, affordability, price, etc. The descriptors of impulse buying behavior are spontaneous, intense, exciting urge to buy (43). Customer likes the products and purchases it, this is known as impulse buying behavior. Individuals buying on impulse are less likely to consider the consequences of purchase or think before making purchase (43). The person's only focuses on relishing urge of purchasing product that they want to rather than fixing any problem or satisfying their prerequisite need. It is a pervasive and distinctive phenomenon and has been receiving increasing attention from consumer researchers and theorists (44). Certain past research has defined impulse buying behavior as irrational behavior (45) and lack of behavioral control (46). Pervasiveness of impulse buying behavior even on the relatively expensive products led researchers to study impulse buying behavior (43). Researchers agree that impulse buying behavior involves a hedonic or affective component (47). Recent study on impulse buying behavior suggest that it more complex and this behavior is to satisfy multiple needs that underlie many types of buying behavior (48). There are different types of internal states and environmental/sensory stimuli that serve as cues for triggering impulse buying behavior (44). Internal cues include customer's state of mind, positive and negative feeling. Environmental/sensory stimuli include atmospheric cues in retail settings, display cues, marketer-controlled cues and marketing mix stimuli (44). This shows how visual merchandising is related to consumer's impulse buying behavior.

\section{Research Objectives and Design}

\subsection{Research Objectives}

1. To explore the dimensions of visual merchandising.

2. To study the impact of visual merchandising on consumer attitude and consumer response in terms of apparel segment.

3. To study the impact of visual merchandising on the impulse buying behavior of the consumers.

\subsection{Research Design, Sample and Data}

The research design is divided into two parts, the first part is exploratory in nature and the second part is descriptive. In the exploratory study the visual merchandiser and marketing manager of the mall were interviewed to understand and find the dimensions of visual merchandising. The study was intended to focus on the impact of visual merchandising in terms of apparel segment as a product category. The sample size of the research was 100 but sixteen were outliers hence, the revised sample size was 84 . The sampling technique was mall intercept method, customer who walk out of the store were surveyed with the help of structured questionnaire. Thus, sampling procedure is purposive sampling. The survey was conducted in Central Mall of Ahmedabad for four days. With the help of SPSS reliability test, factor analysis, correlation and linear regression have been run on the data to get the findings.

From the literature review it is inferred that in terms of visual display, window display, in-store form/mannequin display, floor merchandising and promotional signage, are very important dimension to be studied in visual merchandising. If these dimensions of visual merchandising are properly and innovatively developed, the stores' sales may increase drastically. Window display will increase the walk-ins of the store. Customer once enters the store; the next encounter of the customer with the store happens only if the experience with the store is memorable. In that case in-store form/mannequin display, floor display and promotional signage will play a vital role in making the experience memorable to customer. Therefore, it is important to study the impact of these dimensions on impulse buying behavior of customer, to find out effectiveness of visual merchandising.

\subsection{Research Hypothesis}

H1: Customers who purchase on impulse are influenced by window displays.

H2: Customers who purchase on impulse are influenced by in-store form/mannequin display.

H3: Customers who purchase on impulse are influenced by floor merchandising.

H4: Customers who purchase on impulse are influenced by promotional signage.

The hypotheses are developed from the dimensions found in literature review of visual merchandising. Their relation in terms of visual merchandising is terms of impulse buying behavior are to be found.

The dependent variable of study is impulse buying (section 1in table 1) and independent variables are window display, in-store/mannequin display, floor display, and promotional signage (section 2 to 5 in table 1). These variables have individual constructs which are tested on five point Likert scale which ranged from never $=1$ to frequently $=5$. 
Table 1. Factor Analysis

\begin{tabular}{|c|c|c|c|}
\hline \multirow[t]{2}{*}{ Impulse Buying (Section 1) } & \multirow[t]{2}{*}{ REFERENCES } & \multicolumn{2}{|c|}{ Component } \\
\hline & & 1 & 2 \\
\hline 1. I go shopping to change my mood & \multirow{7}{*}{$\begin{array}{c}1,3,4 \& 5(26), 2(27 \\
28,29) .\end{array}$} & .226 & .822 \\
\hline 2. I feel a sense of excitement when I make an impulse purchase & & .829 & .269 \\
\hline 3. After I make an impulse purchase I feel regret & & .785 & -.236 \\
\hline 4. I have difficulty controlling my urge to buy when I see a good offer & & -.023 & .860 \\
\hline 5. When I see a good deal I tend to buy more than I intended to buy & & .763 & .282 \\
\hline \multirow{2}{*}{$\begin{array}{l}\text { Component Eigen value } \\
\% \text { of Variance Explained }\end{array}$} & & 2.227 & 1.333 \\
\hline & & $45 \%$ & $27 \%$ \\
\hline Influence of Window Display (Section 2) & REFERENCES & \multicolumn{2}{|c|}{1} \\
\hline 6. I feel compelled to enter the store when I see an interesting window display & \multirow{4}{*}{$6,7(30,31,32,33)$} & \multicolumn{2}{|c|}{.833} \\
\hline 7. I tend to enter the store when I am attracted by an eye-catching window display & & \multicolumn{2}{|c|}{.833} \\
\hline Component Eigen value & & \multicolumn{2}{|c|}{1.388} \\
\hline$\%$ of Variance Explained & & \multicolumn{2}{|c|}{$69 \%$} \\
\hline Influence of In-Store Form/Mannequin Display (Section 3) & REFERENCES & 1 & 2 \\
\hline 8. When I see clothing featuring a new style or design on display I tend to buy it & \multirow{6}{*}{$\begin{array}{c}8,9(27), 10(34), 11 \\
(35,36,18) .\end{array}$} & .869 & -.023 \\
\hline 9. I get idea about what to buy after looking through in-store or mannequin display & & .831 & .146 \\
\hline 10. I tend to rely on store displays when I make a decision to purchase clothing. & & -.137 & .883 \\
\hline 11. When I see clothing that I like on in-store or mannequin display I tend to buy it & & .342 & .768 \\
\hline Component Eigen value & & 1.747 & 1.225 \\
\hline$\%$ of Variance Explained & & $44 \%$ & $31 \%$ \\
\hline Influence of Floor Merchandising (Section 4) & REFERENCES & \multicolumn{2}{|c|}{1} \\
\hline 12. I tend to try on clothing that catches my eye when I pass by & & & \\
\hline 13. When I see clothing that catches my eye I tend to try it & & & \\
\hline 14. When I walk along the isle I tend to look through clothing close to me & $12,14(34), 13(35)$ & & \\
\hline Component Eigen value & & & \\
\hline$\%$ of Variance Explained & & & \\
\hline Influence of Promotional Signage (Section 5) & REFERENCES & & \\
\hline 15. When I see a special promotion sign, I go to look at that clothing & & & \\
\hline 16. If I see an interesting promotional offer on in-store signs I tend to buy & & & \\
\hline 17. Sales sign entice me to look through the clothing & $16(37), 15(26) 17$ & & \\
\hline 18. I am more likely to make an unintended purchase if the clothing has a sale sign & $\begin{array}{l}(21,28), 18(29,20 \\
33,18)\end{array}$ & & \\
\hline Component Eigen value & & & \\
\hline$\%$ of Variance Explained & & & \\
\hline
\end{tabular}

Extraction Method: Principal Component Analysis with varimax extraction. 
Table 2. Correlation with Impulse Buying

\begin{tabular}{|c|c|c|}
\hline Variables & Pearson Coefficient & Significance (p) \\
\hline Window Display & 0.425 & 0.000 \\
\hline Form/mannequin Display & 0.214 & 0.051 \\
\hline Floor Merchandising & 0.395 & 0.000 \\
\hline Promotional Signage & 0.512 & 0.000 \\
\hline
\end{tabular}

Table 3. Hypotheses and conclusion with determining coefficients and p-values from regression analysis

\begin{tabular}{|c|c|c|c|c|c|}
\hline Hypothesis & Intercept & Slope & $\begin{array}{c}\text { R Square } \\
\text { Co-efficient }\end{array}$ & p-value & Conclusion \\
\hline $\mathrm{H} 1$ & 2.602 & $\begin{array}{c}0.372 \\
(4.247) \#\end{array}$ & 0.180 & 0.000 & $\begin{array}{c}\text { Customer's impulse buying behavior and window display } \\
\text { has direct relationship. }\end{array}$ \\
\hline $\mathrm{H} 2$ & 2.916 & $\begin{array}{c}0.282 \\
(1.980) *\end{array}$ & 0.046 & 0.051 & $\begin{array}{c}\text { Customer's impulse buying behavior and in-store } \\
\text { form/mannequin display are related but there is no direct } \\
\text { relationshin }\end{array}$ \\
\hline $\mathrm{H} 3$ & 2.789 & $\begin{array}{c}0.359 \\
(3.891) \#\end{array}$ & 0.156 & 0.000 & $\begin{array}{c}\text { Customer's impulse buying behavior and floor } \\
\text { merchandising are related directly. }\end{array}$ \\
\hline $\mathrm{H} 4$ & 2.223 & 0.473 & 0.262 & 0.000 & $\begin{array}{c}\text { Customer's impulse buying behavior and promotional } \\
\text { cionace are related directlv }\end{array}$ \\
\hline
\end{tabular}

t- values in parenthesis * Insignificant \#Significant

\section{Analysis and Findings}

The analysis of the data is carried out in the following step. The preliminary test run are frequency table, principal component analysis and reliability test. While for hypothesis testing regression analysis was carried out. First reliability test for all five variables was carried out. The Cronbach's Alpha of the reliability test was 0.69 for impulse purchase, 0.7 for window display, and 0.702 for in-store form/mannequin display, 0.699 for floor merchandising and 0.69 for promotional signage, which means the questionnaire is reliable.

For hypothesis testing, question 2 of section 1 , as it has the highest value 0.829 in component 1 of principal component matrix with Eigen value 2.22 and percentage of variance explained $45 \%$, in dependent variable checked over with various independent variables (Table: 1 ). For first hypothesis (H1) independent variable from section 2 is question 6 as the value in both the component is same hence, first component is taken for analysis with value 0.833 with Eigen value 1.388 and percentage of variance explained 69\% (Table: 1). For second hypothesis (H2) independent variable from section 3 is question 8 as the value in first component is highest 0.869 with Eigen value 1.747 and percentage of variance explained 44\% (Table: 1). For third hypothesis (H3) independent variable from section 4 is question 12 as the value of the same is 0.838 with Eigen value 1.467 and percentage of variance explained is $48 \%$ (Table:1). For fourth hypothesis (H4) independent variable from section 5 is question 15 as the value is highest 0.890 with Eigen value 2.744 and percentage of variance explained is $69 \%$ (Table: 1 ).

Pearson correlation tests were conducted to see the correlations between the dependent variable (impulse buying) and independent variables (Table 2). In addition linear regression analysis was conducted for the hypothesis testing using impulse buying tendency as a dependent variable and each visual merchandising variable (Table 3 ).

H 1: In the result of a Pearson correlation test, a significant correlation was shown between impulse buying and window display. The data provided sufficient evidence that window display was significantly related with customers' impulse buying behavior. The regression analysis also found that window display has weak significance on customers' impulse buying behavior. This suggested that there was a directional relationship where window display significantly influenced customers' impulse buying behavior. Hence, making window attractive would definitely fetch more footfalls in the store.

H2: The Pearson correlation test resulted that there is no significant correlation between impulse buying and in-store form/mannequin display. In consistence with the result of the correlation test, the regression analysis found that in-store form/mannequin display also did not significantly influence customers' impulse buying behavior. Even the regression analysis did not show positive relation of impulse buying with in-store form/mannequin display. Hence, respondents are not able to empathize with the mannequin display, which is not generating impulse buying behavior from this particular dimension.

H3: The result of a Pearson correlation test found a significant correlation between impulse buying and floor merchandising. The regression analysis suggested that the floor merchandising has weak correlation on customers' impulse buying behavior. The data provides sufficient evidence that there was a significant directional relationship between customer's impulse buying behavior and floor merchandising suggesting that although customers' impulse buying behavior and floor merchandising are correlated.

H4: The Pearson correlation test found a significant correlation between impulse buying and promotional 
signage. As expected, the regression analysis found that promotional signage significantly influenced customers' impulse buying behavior. The $\mathrm{R}$ square value also showed positive relation of promotional signage with impulse buying behavior. This result suggests that promotional signage significantly influenced customers' impulse buying behavior.

\section{Conclusion}

This study investigated some external factors that influence impulse buying behavior as it is immediate with no pre-purchase decision. The results proved that there is a pivotal relationship between customers' impulse buying behavior and window display, floor merchandising and promotional signage. Even though, in-store form/mannequin display did not significantly lead to customers' impulse buying behavior, the results still suggested that this variable and consumers' impulse buying behavior are correlated. When consumers are exposed to these visual stimuli, they more likely make purchase decisions on impulse. This suggests that these visual merchandising practices, serving as stimuli that provoke a desire that ultimately motivates a consumer to make an unplanned purchase decision upon entering the store, significantly influence consumers' impulse buying behaviors. In-store browsing appears to be positively affected by consumers' impulse buying tendency, and in turn, has a positive impact on consumers' positive feelings and impulse buying urges (37). Marketers must use this findings efficaciously to increase sales of their store and innovate themselves in terms of display. Since, window display is the first touch point of store with the customers. Hence, it should be very attractive which should be able to generate impulse buying. Promotional signage and floor display will enhance the experience of the store. Promotional signage should be clear so that customers do not have problem and also does not require salesperson's help. Racks, gondolas, focal point, walking space must give shoppers ease while shopping. Hence, floor display and promotional signage should be very effective. So marketers must use these dimensions creatively. This study has revealed usefulness and effectiveness of visual merchandising in understanding consumers' behavior of impulse buying.

\section{REFERENCES}

[1] AT Kearney (2011), "The Global Retail Development Index: Lessons Learned from Decade of Retail Expansion”, 2011.

[2] McKinsey (2011) Report on Indian Retail Sector.

[3] Walters, D and White, D. (1987), Retail Marketing Management, Basingstock: Macmillan Press.
[4] Mills, K. H., Paul, J.E. \& Moorman, K.B., (1995), Applied visual merchandising (3rd ed.), Englewood Cliffs, New Jersey: Prentice-Hall.

[5] Quartier K, Vanrie J \& Van Cleempoel K, (2009), "The interaction between interpreted space, mood and behavior in retail environments: a conceptual research model", IASDR09 'Design: Rigor and relevance, pp 2-4.

[6] Mattew L. Tullman \& Clark K. Rose, (2004), "Revitalizing Visual Merchandising-Restoring balance to retail environment entails engaging all five senses", 1-2.

[7] Darden, W.R., Erdem,O. \& Darden, D.K. (1983), “A comparison and test of three casual models of patronage intentions", Patronage Behavior and Retail Management, New York, NY: North Holland.

[8] Jiyeon Kim, (2003), “College Students' Apparel Impulse Buying Behaviors in Relation to Visual Merchandising", pp 45-49.

[9] Omar, O. (1999), Retail Marketing, Pitman Publishing, London.

[10] McGoldrick, P. (1990), Retail Marketing, McGraw-Hill, Maidenhead.

[11] McGoldrick, P. (2002), Retail Marketing (2nd Edition), McGraw-Hill, Maidenhead.

[12] Kotler, P. (1974), "Atmospherics as a marketing tool", Journal of Retailing, Vol.49, 48-64.

[13] Bitner, M.J. (1992), "Services capes: the impact of physical surroundings on customers and employees", Journal of Marketing, Vol.56, 57-71.

[14] Davies, B. and Ward, P. (2002), Managing Retail Consumption, Wiley, London.

[15] Levy, M. and Weitz, B A (1996), Essentials of Retailing, Irwin, Chicago, IL.

[16] Berman, B and Evans, J R (1995), Retailing Management: A Strategic Approach (6th edition), Prentice Hall, London.

[17] Buchanan, C, Simmons, CJ and Bickart, B A (1999), "Brand Equity Dilution: retailer display and context brand effects", Journal of Marketing Research, Vol.36 No. 3, p. 345.

[18] Dua, S and Karolia, A. (2008), "Visual Merchandising - 'The changing scenario"', fibre2fashion.com

[19] Erlick,J (1993), "Visual merchandising: Seeing is believing", Home Furnishings Daily, 27 September, pp 13-14.

[20] Fiore A. M., Yah X. and Yoh E., (2000), "Effects of the Product Display and environmental fragrancing on approach responses and pleasurable experiences", Psychology \& Marketing, Vol. 17 (1), pp. 27-42.

[21] Donovan, R. J. \& Rossiter, J.R., Marcoolyn G. \& Nesdale, A. (1994), "Store Atmosphere and Purchasing Behavior", Journal of Retailing, 70, 283-294.

[22] Zeithaml, V. (1988), "Consumer perception of price, quality and value: a means-end model and synthesis of evidence", Journal of Marketing, Vol.52, 2-22.

[23] Treblanche, N. S. (1999), "The perceived benefit derived from visits to a super-regional shopping centre", South 
African Journal of business, Vol. 30 No. 4, 41-6.

[24] Baker, J. and Grewal, D. (1992), “An experimental approach to making retail store environmental decisions", Journal of Retailing, Vol. 68, 445-60.

[25] Baker, J., Grewal, D., Levy, Parasuraman, A. and Glenn, B. (2002), "The influence of multi-store environmental clues on perceived merchandise valve and patronage intentions", Journal of Marketing, Vol. 66,120-41.

[26] Youn, S. \& Faber, R.J. (2000), "Impulse buying: Its relation to personality traits and cues", Advances in Consumer Research, 27, 179-186.

[27] Han Y.K. (1987), "Impulse buying behavior of apparel purchasers", Unpublished master's thesis, Colorado State University, Fort Collins.

[28] Rook, D. W. \& Hoch, S.J. (1985), "Consuming impulses", Advances in Consumer Research, 12, 23-7.

[29] Weun, S., Jones, M.A. \& Beatty, S.E. (1998), "The development and validation of the impulse buying tendency scale", Psychological Reports, 82, 1123-1133.

[30] Gopal V, (2006). Visual Merchandising: An Introduction, pp 4-5.

[31] Bhalla and Anurag, (2010), Visual Merchandising, Tata McGraw Hill, pp. 162-177.

[32] Dawes, C. (2008), "Visual Merchandiser", http://www.sunburysc.vic.edu.au/pdfs/newsletters/Septembe r2008.pdf, accessed on 12/03/2012.

[33] Iqbal, A., Umer, H., Maqbool, A., Sunil, N., Pillai, K., (2011), "Design, Effectiveness and Role of Visual Merchandising in Creating Customer Appeal", MPRA Paper No. 30365.

[34] Rook, D. W. \& Fisher, R.J. (1995). "Trait and normative aspects of impulsive buying behavior", Journal of Consumer Research, 22 (3), 305-13.

[35] Kerfoot, S., Davies, B., Ward, P. (2003), "Visual Merchandising and the Creation of Discernible Retail Brands", International Journal of Retail and Distribution Management.
[36] Clark. D. (2007), "Visual Merchandising and Store Design", http://vmsd.com/content/seibu-jakarta-indonesia-0, accessed on $12 / 03 / 2012$.

[37] Beatty, S.E. \& Ferrell, M.E. (1998), "Impulse buying: Modeling its precursors", Journal of Retailing, 74 (2), 169-191.

[38] Loudon, D. L. \& Della, B. (1993), "Consumer Behavior Concepts and Application", 4th edition, McGraw Hill.

[39] Schiffman, L. G. \& Kanuk, L. L. (2007), "Consumer Behavior", 10th edition, Pearson Publication.

[40] Blackwell, R. D., Miniard, P. W., Engel, J. F., Ching, P. D., (2001), "Consumer Behavior", 10th edition, Cengage Publication.

[41] Solomon, M., Bamossy, G., Askegaard, S., Hogg, M. K. (2009), "Consumer Behavior: A European Perspective", 4th edition, Prentice Hall.

[42] Graves, P, (2010), “Consumerology: The Market Research Myth, The Truth about Consumers and The Psychology of Shopping", Nicholas Brealey Publishing.

[43] Rook, D. W. (1987), "The Buying Impulse", The Journal of Consumer Research, vol, 14, no. 2, pp. 189-199.

[44] Youn, S. and Faber, R. J. (2000), "Impulse Buying: Its Relation to Personality Traits and Cues", Advances in Consumer Research, vol 27, pp. 179-185.

[45] Rook, D. W. \& Fisher, R. J. (1995), "Traits and Normative Aspects of Impulse Buying Behavior", Journal of Consumer Research, vol 22, no. 3, pp. 305-313.

[46] Solnick, J.V., Kannenberg, C.H., Eckerman, D.A. \& Waller, M.B. (1980), "An experimental analysis of impulsivity and impulse control in humans", Learning and Motivation, 11, 61-77.

[47] Weun, S., Jones, M.A. \& Beatty, S.E. (1998), "The development and validation of the impulse buying tendency scale", Pychological Reports, vol. 82, pp.1123-1133.

[48] Hausman, A. (2000), "A multi-method investigation of consumer motivations in impulse buying behavior", Journal of Consumer Marketing, vol. 17, pp. 403-419. 